\title{
CURRÍCULOS INTRA/INTERCULTURAL NA BOLÍVIA: a matemática e a perspectiva pós-colonial
}

\author{
INTRA/INTERCULTURAL CURRICULA IN BOLIVIA: \\ mathematics and the post-colonial perspective
}

CURRÍCULOS INTRA/INTERCULTURAL EN BOLIVIA:
la matemática y la perspectiva post-colonial

\author{
Harryson Júnio Lessa Gonçalves \\ Professor Doutor da Universidade Estadual Paulista (UNESP). \\ São Paulo-SP, Brasil. \\ hlessa@gmail.com \\ Antônio Hilário Aguilera Urquiza \\ Professor Doutor da Universidade Federal de Mato Grosso (UFMS). \\ Campo Grande - MS, Brasil. \\ hilarioaguilera@gmail.com
}

\begin{abstract}
Resumo: O artigo tem como objetivo descrever, a partir de documentos curriculares, o processo de planificação dos currículos regionalizados do Estado Plurinacional da Bolívia. Para tanto, tem como objetivos específicos: a) identificar a organização e estrutura o sistema educacional boliviano a partir de algumas características sociais, histórica e econômicas; b) identificar pressupostos teóricos que consubstanciam a reforma curricular boliviana; c) descrever a organização curricular de Matemática no ensino secundário (Ensino Médio) viabilizada pelos currículos bolivianos. A investigação foi desenvolvida a partir de documentos curriculares que, pressupomos, são pouco conhecidos no Brasil e, por isso, como estratégia para afirmação da identidade latino-americana no Brasil. Assim, o estudo foi produzido a partir de pesquisa bibliográfica (artigos sobre ensino de Matemática na Bolívia) e documental (análise de documentos e currículos oficiais da Bolívia). Desse modo, nos consubstanciamos em um referencial teórico pós-colonial. O currículo analisado nos revelou um compromisso com a educação centrada em aspectos antropológicos que toma o conhecimento como histórica e socialmente posicionado a partir da diversidade cultural, valorizando, assim, saberes providos de povos indígenas originários; percebemos, ainda, um currículo distanciado de bases conceituais e epistemológicas preconizadas pela comunidade internacional de educadores matemáticos.
\end{abstract}

Palavras-chave: Currículo de matemática. Bolívia. Educação boliviana.

Abstract: The article aims to describe, from curricular documents, the process of planning the region's curriculum, of the Sate of Plurinational of Bolivia. To do so, it has specific objectives: a) to identify the organization and structure of the Bolivian educational system based on some social, historical and economic characteristics; $b$ ) to identify theoretical assumptions that underpin Bolivian curricular reform; c) describe the curricular organization of Mathematics in secondary education (Middle School) made possible by Bolivian curriculum. For that, the research was developed from curricular documents that, we assume, are little known in Brazil and, therefore, as a strategy for affirming the Latin American identity in Brazil. Thus, the study was produced from bibliographical research (articles on teaching Mathematics in Bolivia) and documentary (analysis of official documents and curricula from Bolivia). Therefore, we are based on a post-colonial theoretical framework. The curriculum analyzed showed us a commitment to education centered on anthropological aspects that takes knowledge as historical and socially positioned from cultural diversity, thus valuing the knowledge provided by native indigenous peoples; We also notice, a curriculum distanced from the conceptual and epistemological bases advocated by the international community of mathematical educators.

Keywords: Mathematics curriculum. Bolivia. Bolivian education.

Resumen: El objetivo del artículo es describir, a partir los documentos curriculares, el proceso de planificación de los currículo regionalizados del Estado Plurinacional de Bolivia. Para ello, tenemos como objetivos específicos: a) identificar la organización y estructura del sistema educativo boliviano a partir de algunas características sociales, históricas y económicas; b) identificar los fundamentos teóricos que aportan la reforma curricular boliviana; ci) describir la organización curricular de Matemáticas en la educación secundaria viabilizada por los currículos bolivianos. La investigación fue desarrollada a partir de documentos curricular que, presumimos, son poco conocidos en Brasil y, por eso, se presenta como estrategia para la afirmación de la identidad latinoamericana en Brasil. Así, el estudio fue 
producido a partir de investigación bibliográfica (artículos sobre Enseñanza de Matemáticas en Bolivia) y documental (análisis de documentos y currículos oficiales de Bolivia). De ese modo, nos basamos en un marco teórico pos-colonial. El currículo analizado nos reveló un compromiso con la educación centrada en aspectos antropológicos que parte de un conocimiento histórico y socialmente posicionado a partir de la diversidad cultural, valorando los saberes provenientes de pueblos indígenas originarios; Percibimos también un currículo distanciado de bases conceptuales y epistemológicas preconizadas por la comunidad internacional de educadores matemáticos.

Palabras clave: Currículo de matemática. Bolivia. Educación boliviana.

\section{INTRODUÇÃO}

A "integração" torna-se emergente e é "palavra de ordem" para fortalecimento das nações da América Latina, superando a condição de povos que, desde os primórdios de sua colonização pelos europeus, se encontram imersos em um quadro conflituoso de dominação e crises, além do massacre dos povos daqui originários. Assim, a promoção de tal integração se viabiliza pelo fortalecimento da identidade latino-americana, assentada no histórico de seus povos (formação, lutas e conquistas) e no surgimento de seu ideário de resistência, pautado em sua diversidade cultural, basilar para implementação de políticas sociais e econômicas desses países, suplantando, assim, uma possível normatividade imposta internacionalmente por países hegemônicos.

No Brasil, a integração latino-americana é um preceito encontrado na Constituição Federal (parágrafo único do artigo $4^{\circ}$ ): "a República Federativa do Brasil buscará a integração econômica, política, social e cultural dos povos da América Latina, visando à formação de uma comunidade latino-americana de nações" (BRASIL, 1988, p. 2).

No âmbito científico algumas iniciativas têm proporcionado a integração entre pesquisadores de países latino-americanos vislumbrando o reconhecimento internacional da nossa produção científica latino-americana, em contraponto aos ranqueamentos internacionais que, por vezes, desconsideram nossas especificidades em detrimento de padrões normativos definidos por algumas universidades tradicionais, perspectiva por vezes aceitável no âmbito das Ciências da Natureza em função de sua dependência do aparato tecnológico disponível nessas universidades e centros de pesquisa; contudo, perspectiva discutível no âmbito das Ciências Antropossociais em função do seu impacto social, por vezes de cunho local ou regional.

Podemos ilustrar algumas ações, em geral constituídas no âmbito da esfera pública, que contribuem com a articulação desses pesquisadores latino-americanos: intercâmbio universitário (alunos, professores e pesquisadores); acordos de cooperação internacionais (entre universidade e centros de pesquisa); doutorados sanduíches e pós-doutorados no exterior; participação em reuniões científicas; publicação em periódicos. Todavia, tais ações ainda são inexpressivas, pois a referência de qualidade científica nem sempre se remete às instituições de pesquisa e universidades latinoamericanas, dada a valorização dos ranqueamentos supramencionados.

No campo da Educação Matemática, um exemplo de tal integração é a criação em 2003 da Federação Ibero-Americana de Sociedades de Educação Matemática (Fisem) que agrega diversas sociedades de educadores matemáticos ${ }^{1}$. A Fisem mantém uma revista de divulgação científica, chamada Unión, e é responsável pela organização do Congresso Ibero-Americano de Educação Matemática (Cibem). Outros eventos também mobilizam a comunidade, entre eles a Conferência Interamericana de Educação Matemática (Ciaem), a Reunião de Didática da Matemática do Cone Sul e a Reunião Latino-Americana de Matemática Educativa (PIRES; GONÇALVES, 2015).

Contudo, julgamos tais iniciativas ainda incipientes, pois pouco conhecemos dos aspectos socioculturais dessas nações. Por isso, propomos no presente projeto de investigação discutir sobre o processo de implementação curricular na Bolívia, dada sua configuração de Estado Plurinacional e que se encontra em um processo de reforma curricular, planificando/implementando currículos regionalizados - coordenado pelo Ministério da Educação juntamente com suas diversas nações e povos indígenas, originários campesinos, a partir de um sistema que se caracteriza intracultural, intercultural e plurilíngue.

\footnotetext{
Sociedad Argentina de Educación Matemática (Soarem), Sociedade Brasileira de Educação Matemática (SBEM), Sociedad Chilena de Educación Matemática (Sochiem), Federación Española de Sociedades de Profesores de Matemáticas (FESPM), Asociación Nacional de Profesores de Matemáticas (ANPM, do México), Asociación Mexicana de Investigadores del Uso de Tecnología en Educación Matemática (Amiutem), Sociedad Peruana de Educación Matemática (Sopemat), Associação de Professores de Matemática (APM/Portugal), Sociedad de Educación Matemática de Uruguay (Semur), Sociedad Boliviana de Educación Matemática (SOBEDM), Asociación Venezolana de Educación Matemática (Asovemat), Comité de Educación Matemática de Paraguay (Cempa), Sociedad Ecuatoriana de Matemáticas (Sedem) e a Asociación Colombiana de Educación Matemática (Asocolme).
} 
Assim, apresentamos o seguinte problema de pesquisa: como, a partir de análises de currículos oficiais e outros documentos, tem ocorrido o processo de planificação de currículos regionalizados no Estado Plurinacional da Bolívia?

Ressaltamos que o currículo boliviano é construído na perspectiva de um discurso pós-colonial. O discurso pós-colonial caracteriza-se como uma perspectiva teórica que agrega teorias fundadas na Filosofia, Literatura e Ciência Política, tendo como norte uma reação contra o legado colonial, ou seja, visa a "analisar o complexo das relações de poder entre as diferentes nações que compõem a herança econômica, política e cultural da conquista colonial europeia tal como se configura no presente momento chamado, é claro, de pós-colonial" (SILVA, 2007, p. 125).

Quijano (2000) aponta que a colonialidade é um pressuposto específico e constitutivo do padrão mundial de poder capitalista; subsidia-se na imposição de uma classificação étnico-racial da população do mundo como basilar do padrão de poder e opera em cada um dos planos, âmbitos e dimensões materiais e subjetivas da existência social cotidiana e da escala social. O autor acrescenta ainda que tal colonialidade se originaliza e mundializa a partir da América Latina.

\begin{abstract}
Colonialidade e descolonialidade introduzem uma fratura entre a pós-modernidade e a póscolonialidade como projetos no meio do caminho entre o pensamento pós-moderno francês de Michel Foucault, Jacques Lacan e Jacques Derrida e quem é reconhecido como a base do cânone pós-colonial: Edward Said, Gayatri Spivak e Hommi Bhabba. A descolonialidade em contrapartida - arranca de outras fontes. Desde a marca descolonial implícita na Nueva Crónica y Buen Gobierno de Guamán Poma de Ayala; no tratado político de Ottobah Cugoano; no ativismo e crítica decolonial de Mahatma Ghandi; na fratura do Marxismo em seu encontro com o legado colonial nos Andes, no trabalho de José Carlos Mariátegui; na política radical, o giro epistemológico de Amilcar Cabral, Aimé Césaire, Frantz Fanon, Rigoberta Menchú, Gloria Anzaldúa, entre outros. (MIGNOLO, 2010, p. 14-15, tradução nossa).
\end{abstract}

Portanto, apesar da independência das ex-colônias e da constituição dessas nações, diversos fatores sociais e políticos não garantiram a descolonização, mantendo-se a colonialidade por meio político, cultural, epistêmico, jurídico e administrativo (CALDERONI, 2016). Desse modo, visamos contribuir com tal processo de descolonialidade trazendo à tona algumas características do currículo boliviano que, pressupomos, serem pouco conhecidas no Brasil.

Assim, o artigo tem como objetivo geral descrever, a partir de documentos curriculares, o processo de planificação dos currículos regionalizados do Estado Plurinacional da Bolívia. Para tanto, temos como objetivos específicos: a) identificar a organização e estrutura o sistema educacional boliviano a partir de algumas características sociais, histórica e econômicas; b) identificar pressupostos teóricos que consubstanciam a reforma curricular boliviana; c) descrever a organização curricular de Matemática no ensino secundário (Ensino Médio) viabilizada pelos currículos bolivianos.

\title{
2 O ESTADO PLURINACIONAL DA BOLÍVIA E O SEU PLANO DE DESENVOLVIMENTO ECONÔMICO E SOCIAL
}

A compreensão da sociedade boliviana perpassa pelo conhecimento de seu contexto socioambiental. A Bolívia, apesar de possuir uma localização próxima ao Equador, tem poucos traços comuns aos trópicos; grande parte de seu povo tem vivido a uma altitude bastante elevada de 1.500 a 4.000 metros acima do nível do mar. Todavia, seu ambiente não é totalmente hostil, os planaltos têm solos mais pobres e climas mais secos e frios, enfrentando adversidades que não atingem as planícies. Tais características ecológicas exigiram a domesticação de plantas e animais e tiveram um impacto drástico sobre a psicologia humana, pois as populações do planalto foram forçadas a se adaptar ao limitado suprimento de oxigênio e a níveis de pressão atmosférica muito desiguais (KLEIN, 2004).

Ao se tratar dos povos originários da Bolívia, percebemos, a partir de Klein (2004), uma forte herança cultural milenar - como cultura Chavín (1500 a.C. até 500 a.C.), Tiahuanaco (desde 1500 a.C.), reinos dos Aymara (séculos XII a XVI), além do Império Inca (séculos XIII a XVI).

A Bolívia se tornou, após conquista europeia, foco de interesses na economia mundial em razão de sua herança mineral, pouco explorada nos tempos pré-colombianos (KLEIN, 2004). Contudo, 
apesar da violenta colonização europeia, ainda se revelam fortes traços dessas culturas ancestrais nas tradições do país.

Em 6 de agosto de 1825, após diversas lutas, a Bolívia se tornou independente.

Para o resto do mundo, a nova república de [Simon] Bolívar era uma região mítica, habitada por massas indígenas camponesas e repleta de minas fabulosas. Mas infelizmente a verdade era outra. No ano em que conquistou a independência, a região já experimentava um período de estagnação econômica que duraria quase meio século. De aproximadamente 1803 aos últimos anos da década de 1840, a economia boliviana assistiu a um declínio progressivo na produção de suas minas, à manutenção de um saldo consistentemente negativo em seu comércio internacional e, em consequência, a um processo progressivo de descapitalização que se refletiu no declínio de suas populações urbanas. Os tão importantes centros mineradores de Potosí e Oruro não chegavam a ter juntos 15.000 habitantes em 1827. (KLEIN, 2004, p. 73).

Klein (2004) afirma que em 1827 a população da nova república era estimada de 100.000 cholos, 200.000 brancos e, aproximadamente, 800.000 camponeses índios; assim, a Bolívia se constituiu como a nação mais indígena da América espanhola em que a língua dos colonizadores permaneceu uma língua de minoria até o século XX. O autor acrescenta ainda que "as prósperas colônias mineiras de antigamente emergiram em sua nova existência republicana, como uma sociedade extremamente pobre, composta na esmagadora maioria por índios camponeses" (KLEIN, 2004, p. 73).

Conforme aponta o governo (BOLÍVIA, [2015?]), por meio do Plano de Desenvolvimento Econômico e Social 2016-2020 (PDES), a fundação da República da Bolívia foi o resultado da luta tenaz e o sangue derramado pelos mártires, libertadores e líderes indígenas que viveram no passado nessas terras e territórios, com ideais e sonhos de construção de uma nação soberana, livre, com justiça e igualdade.

O PDES acrescenta ainda que o período de 1825 a 2005 deixou marcado na Bolívia um cenário repleto de desigualdades sociais, políticas e econômicas, refletindo na exclusão da maioria indígena e originários do exercício de seus direitos políticos e de cidadania estatal e gerando uma lacuna entre ricos e pobres. Nesse período, a Bolívia caracterizou-se como um Estado fraco, dominado por interesses externos e elites internas que influenciaram na privatização das riquezas do país, subordinando interesses privados internos e externos produtivos, para criar um modelo de economia orientada para a exportação de matérias-primas e do excedente econômico. Assim, nesse período o Estado republicano ignorou os ideais e sonhos dos que lutaram e libertaram o país (BOLÍVIA, [2015?]).

Em 2006, ascende à gestão do Estado republicano o Presidente Evo Morales Ayma, descendente de povos originários, propondo iniciar uma revolução democrática para constituir um novo Estado e um novo poder com uma visão anticapitalista, anti-imperialista e descolonizadora (BOLÍVIA, [2015?]).

Assim, conforme o PDES, inicia-se uma Revolução Democrática e Cultural no país.

A partir do ano 2006, a Revolução Democrática e Cultural se norteia a construir um Estado plurinacional e comunitário por meio de um processo de mudança que viabiliza as expectativas e necessidades compartilhadas do povo boliviano, que incluem uma profunda transformação das estruturas coloniais e republicanas econômicas, sociais e políticas do país. Deste modo, Bolívia retoma sua soberania e dignidade, onde todas as bolivianas e todos os bolivianos tenham o orgulho de ter nascido na Bolívia. (BOLÍVIA, [2015?], p. 7, tradução nossa).

O documento afirma ainda que no primeiro período da revolução (gestão: 2006 a 2009) se iniciou um processo de transformação das estruturas institucionais do Estado e da sociedade boliviana, culminando na refundação do país e no nascimento do novo Estado Plurinacional./ O segundo período da revolução (gestão: 2010 a 2013), conforme o PDES, se caracterizou pelo empenho de se construir um novo Estado Plurinacional no sentido de se pensar um horizonte para o povo boliviano "Viver Bem", construindo seu próprio espaço histórico e civilizatório. Nesse período, se consolidou uma nova constituição política do Estado, avançando em ações práticas e concretas para realização 
do "Viver Bem", no marco de reconhecimento de um país plural nos aspectos econômico, social, político, cultural e jurídico, a partir da base de um novo modelo econômico, social, produtivo e comunitário.

[...] neste período se constitui um Estado forte, que dirige e planifica suas políticas sociais e econômicas, que exerce a direção e o controle dos setores estratégicos, e participa diretamente na economia e geração de riqueza, para sua distribuição e redistribuição. (BOLÍVIA, [2015?], p. 8, tradução nossa).

No atual terceiro período (gestão: 2014 a 2017), o PDES afirma que o governo está orientado a consolidar a Revolução Democrática Cultural e o Estado Plurinacional por meio do fortalecimento de um Estado integral e do "Viver Bem", em que existe articulação e correspondência entre o povo boliviano e os diferentes níveis de governo, em que todos compõem o Estado, em que há uma forte liderança das organizações sociais e se fortifica a plurinacionalidade, autonomia democrática e soberania econômica.

Neste contexto, continuará fortalecendo a construção de um ser humano integral, se consolidará o modelo econômico, social, comunitário e produtivo, o acesso universal de todas e todos os bolivianos aos serviços básicos fundamentais, o lançamento de um novo modelo ambiental baseado na relação mutualmente benéfica entre o ambiente de vida da natureza e os seres humanos, na convergência e complementaridade virtuosa que deve existir entre os direitos da Mãe Terra e o direito ao desenvolvimento integral de nossos povos e nações no âmbito do Viver Bem. (BOLÍVIA, [2015?], p. 8, tradução nossa).

Concordamos com Ayerbe (2011) que, no governo de Evo Morales, a Bolívia apresenta um cenário consolidado de estabilidade institucional em que se criaram condições estruturais viabilizadoras para o modelo proposto de desenvolvimento, Estado Unitário Social de Direito Plurinacional Comunitário, que expressa jurídica e politicamente as relações sociais do Capitalismo Andino-Amazônico.

O autor acrescenta ainda que recai nas lideranças do processo de transformação o peso da responsabilidade sobre os resultados que, diferente de contextos anteriores, desencoraja processos de reação desestabilizadora, gerando perda de confiança da população nas autoridades, déficits de gestão, divisões na base de apoio do governo, descontentamento social. Assim, com enfraquecimento consequente, lacunas poderão ser abertas para investidas de conservadores contra a falência do Estado, da ordem e do império da lei.

\section{SISTEMA EDUCACIONAL BOLIVIANO}

No tocante à escolarização, segundo o portal do Instituto Nacional de Estatística (INE) ${ }^{2}$ da Bolívia, em 2012 a população boliviana apresentava uma escolarização média de 8,97 anos (sendo a média de 9,55 para homens e 8,41 para mulheres).

Em 2013, o INE revelou que o nível de escolarização alcançado pela população de mais de 18 anos demonstra uma diferença considerável de acesso à escolarização das comunidades campesinas (em geral de origem indígena) à escolarização: pouco mais de $8 \%$ das pessoas não possuem escolarização, sendo esse indicador ampliado para quase $20 \%$ quando considerada apenas a população rural, sendo ainda tal indicador preocupante quando se faz referência às mulheres (12,24\% em relação aos $3,83 \%$ dos homens no total e $29,35 \%$ em relação aos $9,74 \%$ dos homens em zonas rurais). Tais indicadores revelam ainda que 30,85\% da população alcança 0 ensino superior, e na zona urbana esse percentual é de $41,23 \%$, enquanto na zona rural de apenas $6,58 \%$. Dados do INE de 2012 apontam ainda que 5,09\% sofre de analfabetismo, sendo $2,45 \%$ da população analfabeta de homens e $7,67 \%$ de mulheres.

No período de 2003/2004 a 2013, indicadores do INE indicam que o número de habitantes bolivianos com mais de 18 anos não escolarizado reduziu de 13,28\% para 8,23\%, bem como observou-se um aumento de $25,03 \%$ para $39,7 \%$ de habitantes com educação secundária. No ensino superior tal indicador sobe de $16,92 \%$ para $30,85 \%$.

Bolívia (2012b). 
No período de 2006 a 2013, as matrículas na educação secundária tiveram uma elevação significativa de 533.041 para 960.009 . No mesmo período houve um aumento de $126 \%$ do número de matrículas na educação superior pública do país.

O sistema educacional boliviano é organizado a partir da Lei da Educação no 070 (Lei "Avelino Siñani - Elizardo Pérez"), de 20 de dezembro de 2010; a Lei conta com 92 artigos, além de disposições transitórias, obrigatórias e finais. Assim, neste tópico caracterizaremos tal sistema educacional a partir dos preceitos da referida lei.

A lei assume que a educação se sustenta na sociedade, por meio da participação plena dos bolivianos no sistema educativo plurinacional, respeitando suas diversas expressões sociais e culturais nas suas diferentes formas de organização, bem como encontra-se alinhada, em suas bases, com o processo de consolidação da Revolução Democrática e Cultural de Evo Morales.

[A educação] é descolonizadora, liberadora, revolucionaria, anti-imperialista, despatriarcalizadora e transformadora das estruturas econômicas e sociais; orientada para reafirmação cultural das nações e povos indígenas originários campesinos, as comunidades interculturais e afro-bolivianas na construção do Estado Plurinacional e o Viver Bem. (BOLÍVIA, 2010, p. 4, tradução nossa).

A lei garante a todas as pessoas o direito à educação em todos os níveis de maneira universal, produtiva, gratuita, integral e intercultural, sem discriminação, tornando a educação obrigatória até o bachillerato.

A lei representa um marco para valorização das populações originárias por evidenciar a inclusão a partir da diversidade cultural do povo boliviano, estabelecendo, inclusive, que a língua a ser ensinada deve ser a língua materna, e não apenas o castelhano/espanhol. A lei ressalta que nas comunidades em que se fala mais de uma língua os conselhos comunitários decidirão qual a língua a ser ensinada. Assim, a lei garante o seu preceito de que a educação é intracultural, intercultural e plurilíngue em todo o sistema educativo.

A lei compreende o Sistema Educativo Plurinacional a partir de três subsistemas: a) Educação Regular; b) Educação Alternativa e Especial; c) Educação Superior de Formação Profissional. Tais subsistemas serão explicitados nos itens a seguir, a partir da Lei "Avelino Siñani - Elizardo Pérez".

\subsection{Educação Regular}

A Educação Regular é obrigatória, sistemática, normatizada e processual, oferecida a crianças, adolescentes e jovens, desde a Educação Inicial em Família Comunitária até o Bacharelado, permitindo o desenvolvimento integral e oportunidades de continuidade dos estudos na Educação Superior de Formação Profissional, bem como projeção no âmbito produtivo. Tal sistema tem caráter intracultural, intercultural e plurilíngue.

A Educação Regular é dividida em três níveis: a) Educação Inicial em Família Comunitária; b) Educação Primária Comunitária Vocacional; c) Educação Secundária Comunitária Produtiva.

A Educação Inicial em Família Comunitária possui cinco anos de duração, sendo dividida em duas etapas:

a) Educação Inicial em Família não Escolarizada - com três anos de duração, sendo de responsabilidade compartilhada entre família, comunidade e o Estado; é orientada para recuperar, fortalecer e promover a identidade cultural, apoio à família na promoção de saúde e boa nutrição da criança visando o seu desenvolvimento psicomotor, socioafetivo, espiritual e cognitivo.

b) Educação Inicial em Família Escolarizada - com dois anos de duração, visa ao desenvolvimento das capacidades e habilidades cognitivas, linguísticas, psicomotoras, socioafetivas, espirituais e artísticas que favoreçam atitudes de autonomia, cooperação e tomada de decisões no processo de construção do seu pensamento, para iniciar processos de aprendizagens sistemáticos no nível seguinte.

A Educação Primária Comunitária Vocacional tem seis anos de duração e compreende a formação básica, fundamental para todo o processo de formação posterior. Os conhecimentos e a formação qualitativa dos estudantes, em relação e afinidade com os saberes, as ciências, as culturas, a natureza e o trabalho criativo, orienta sua formação. Esse nível deve proporcionar 
condições necessárias de permanência dos estudantes, desenvolvimento de suas capacidades comunicativas, ético-morais, espirituais, raciocínios lógicos, científicos, técnicos, tecnológicos e produtivos, educação física, desportista e artística.

A Educação Secundária Comunitária Produtiva possui seis anos de duração. Articula a educação humanística e técnica-tecnológica com a produção que valora e desenvolve os saberes e conhecimentos das diversas culturas em diálogo intercultural com o conhecimento universal, incorporando a formação histórica, cívica e comunitária. Fortalece a formação recebida no nível anterior por ser integral, científica, humanística, técnica-tecnológica, espiritual, ética, moral, artística e desportista. Tal nível permite identificar nos estudantes as vocações para continuar estudos superiores ou incorporar-se nas atividades socioprodutivas. Em tal nível de formação ocorre a obtenção do diploma de Bacharel Técnico Humanístico e, de maneira progressiva, com o grau de Técnico Médio.

\subsection{Educação Alternativa e Especial}

Destinada a atender necessidades e expectativas educativas de pessoas, famílias, comunidades e organizações que precisar dar continuidade a seus estudos ou de formação permanente. Para tanto, desenvolve-se com enfoque de Educação Popular e Comunitária, Educação Inclusiva e Educação ao longo da vida, priorizando populações em situação de exclusão, marginalização e discriminação. Pauta-se ainda no reconhecimento de saberes, conhecimentos e experiências das pessoas, adquiridos em sua prática cotidiana e comunitária.

O subsistema de Educação Alternativa e Especial adotará o caráter técnico-humanístico segundo as necessidades e expectativas das pessoas, família e comunidades de acordo com os avanços da Ciência e Tecnologia. Tal educação conferirá as seguintes certificações: técnico básico, técnico auxiliar e técnico médio, possibilitando o ingresso na Educação Superior ou incorporação no setor produtivo.

Tal subsistema compreende os âmbitos de Educação Alternativa e Educação Especial. A Educação Alternativa é destinada a pessoas jovens e adultos com mais de 15 anos que pretendem continuar seus estudos. Para tanto, é organizada em dois níveis: Educação Primária de Jovens e Adultos (envolve alfabetização e pós-alfabetização) e Educação Secundária de Jovens e Adultos. A Educação Especial responde às necessidades, expectativas e interesses de pessoas com necessidades educativas especiais (na lei são encontrados os seguintes termos: incapacidade, pessoas com dificuldades de aprendizagem e pessoas com talento extraordinário), desenvolvendo sua ação em articulação com a Educação Regular, Alternativa e Superior.

\subsection{Educação Superior de Formação Profissional}

A Educação Superior de Formação Profissional é composta por: Formação de Professores (Maestras/Maestros); Formação Técnica e Tecnológica (FTT); Formação Superior Artística; Formação Universitária.

A Formação de Professores (Maestras/Maestros) compreende a formação de professores para atuar nos subsistemas de Educação Regular e Educação Alternativa e Regular, com a seguinte estrutura: Formação Inicial de Professores; Formação Pós-Graduada de Professores; Formação Contínua de Professores.

A Formação Inicial de Professores se desenvolve em Escuelas Superiores de Formación de Maestras y Maestros, instituições de caráter fiscal e gratuito dependente do Ministério da Educação (MEC). O currículo de formação de professores é único para todo o país, abrangendo a formação geral e especializada com duração de cinco anos com grau de licenciatura. A Formação PósGraduada de Professores ocorrerá em Universidades Pedagógicas credenciadas pelo MEC. A Formação Contínua é um direito e um dever dos professores, estando orientada a partir de sua atualização e capacitação para melhorar a qualidade da gestão, dos processos, dos resultados e do ambiente educativo, fortalecendo as capacidades inovadoras dos educadores, e tal formação ficará a cargo de instâncias especializadas abaixo do MEC.

A FTT promove formação profissional técnica e integral, articulada com desenvolvimento produtivo, sustentável e auto gestionário, de caráter científico, prático-teórico e produtivo oferecida pelas seguintes instituições: Institutos Técnicos, Institutos Tecnológicos e Escolas Superiores 
Tecnológicas. A FTT se desenvolverá pelos seguintes níveis: (1) Institutos Técnicos e Institutos Tecnológicos (de carácter fiscal, privado e convênio) - (a) Capacitação; (b) Técnico Médio pós-bacharelado; (c) Técnico Superior; (2) Escolas Superiores Tecnológicas Fiscais - a) Nível Licenciatura3; b) Diplomado Técnico.

A Formação Superior Artística visa ao desenvolvimento de capacidades, competências e destrezas artísticas, articulando teoria e prática, para o fortalecimento das expressões culturais e o desenvolvimento das qualidades criativas dos bolivianos. Os níveis de formação artísticas são: (1) Centros de Capacitação Artística; (2) Institutos de Formação Artística: a) Nível Capacitação b) Nível Técnico Médio c) Nível Técnico Superior; (3) Escolas Bolivianas Interculturais - Nível Licenciatura.

A Formação Universitária é um espaço de preparação de profissionais, de desenvolvimento científico e tecnológico, promovida em instituições universitárias (universidades públicas autônomas, universidades privadas, universidades indígenas e universidades de regime especial - militar e policial). Tal formação se organiza a partir dos seguintes níveis e graus: (1) Graduação (pre grado): Técnico Superior, Licenciatura; (2) Pós-Graduação (Post grado): Diplomado, Especialização, Mestrado, Doutorado e Pós-Doutorado.

\section{CURRÍCULO DE MATEMÁTICA DE ENSINO MÉDIO NA BOLÍVIA}

A Lei da Educação nº 070/2010 (Lei "Avelino Siñani - Elizardo Pérez") dispõe que a organização curricular deve estabelecer mecanismos de articulação entre a teoria e a prática educativa; a lei estabelece ainda que o currículo deve ser construído a partir de uma base intracultural que, em sua complementaridade, garanta a unidade e a integralidade do sistema educativo plurinacional, assim como o respeito à diversidade cultural e linguística da Bolívia (BOLÍVIA, 2010).

O currículo base plurinacional boliviano é desenhado, aprovado e implementado pelo MEC com a participação dos diversos atores educativos. Cabe ainda ao Ministério apoiar a planificação dos currículos regionalizados, em coordenação com as nações e povos indígenas originários campesinos, preservando uma harmonia e complementaridade com o currículo base plurinacional. Tais currículos regionalizados são de competência do Estado (via MEC) e das entidades territoriais autônomas (BOLIVIA, 2010).

O currículo base plurinacional estabelece os princípios e os objetivos da organização curricular que emergem das necessidades da vida e da aprendizagem das pessoas e da coletividade. $O$ currículo regional apresenta as características do contexto sociocultural e linguístico das nações e povos indígenas originários no qual desenvolve processos educativos produtivos comunitários de acordo com suas vocações produtivas (BOLÍVIA, 2010).

Para fins deste trabalho, optamos por identificar características do documento "Educação Secundária Comunitária Produtiva: Programa de Estudo - Primeiro ano" (BOLÍVIA, 2012a). Tal documento encontra-se disponível no portal do MEC e, por estar em processo de implementação curricular, não foi possível ter acesso aos documentos dos demais anos/séries letivas. Pressupomos que o currículo está sendo implementado progressivamente, e, para compreensão do currículo anterior, recomendamos a leitura de Grigoriu (2005).

Ressaltamos ainda que o currículo boliviano tem sido planificado/implementado a partir do Programa de Formação Complementar de Professores (maestras/maestros) em Exercício(Profocom), que envolve Escolas Superiores de Formação de Professores, Unidades Acadêmicas e Universidade Pedagógica. Conforme aponta Grigoriu (2014), ao fazer referência às ações da Sociedade Boliviana de Educação Matemática (Soboedma), diz que nos últimos anos a Soboedma não tem provido encontros, pois os professores estão centrando seu tempo e atenção no processo formativo obrigatório pelo governo por conta da nova Lei de educação - o Profocom. Assim, pressupomos que tal ação mobiliza a totalidade de professores bolivianos no processo de planificação/implementação curricular da "Grande Revolução Educativa", conforme aponta Grigoriu (2014).

A proposta curricular da educação secundária boliviana é organizada por: Campos e Áreas de Saberes e Conhecimentos; Eixos Articuladores.

Os campos de saberes e conhecimentos, distinta da organização disciplinar dos conteúdos, é uma categoria ordenadora e articuladora das áreas e conteúdos de modo não fragmentado que estabelece vínculos e laços entre os conhecimentos disciplinares para evitar que estes se

3 O termo "licenciatura" na Bolívia (e em outros países latino-americanos) refere-se à graduação superior plena, nem sempre sendo equivalente ao termo utilizado no Brasil - inerente aos cursos de formação de professores de nível superior para Educação Básica. 


\section{Harryson Júnior Lessa Gonçalves e Antônio Hilário Aguilera Urquiza}

mantenham na condição fragmentada e especializada. Tais campos funcionam como instrumento que nos permite agrupar áreas de saberes e conhecimentos a fim de que se tenha uma perspectiva integral do conhecimento de maneira operativa e que sirva ao mesmo tempo como modo de pensar integralmente os conhecimentos (BOLÍVIA, [2014?]). [2014?]):

O currículo é organizado a partir de quatro áreas de saberes e conhecimentos (BOLIVIA,

a) Vida, Terra e Território - Ordena os conhecimentos em função da recuperação do sentido da vida e com a terra orientando uma relação harmônica e complementária evitando a tendência destrutiva do atual modo de vida capitalista globalizado.

b) Ciência, Tecnologia e Produção - Orientado ao rompimento de dependência econômica da Bolívia tentando se adaptar, potencializar e produzir tecnologias próprias e usando-as na realidade do país.

c) Comunidade e Sociedade - Orientado a recuperar a vida comunitária e seus valores superando uma tendência individualista, de caráter autodestrutivo, de crises de valores e violência da sociedade atual.

d) Cosmo e Pensamento - Contribui para a descolonização da mentalidade (colonizada) incorporando uma visão intercultural de aprendizagem mútua, distintas cosmovisões de vida e compreensão da espiritualidade.

Na figura 1 apresentamos um esquema da organização dos campos e áreas de conhecimentos do currículo boliviano.

Figura 1 - Campos e áreas de saberes e conhecimentos
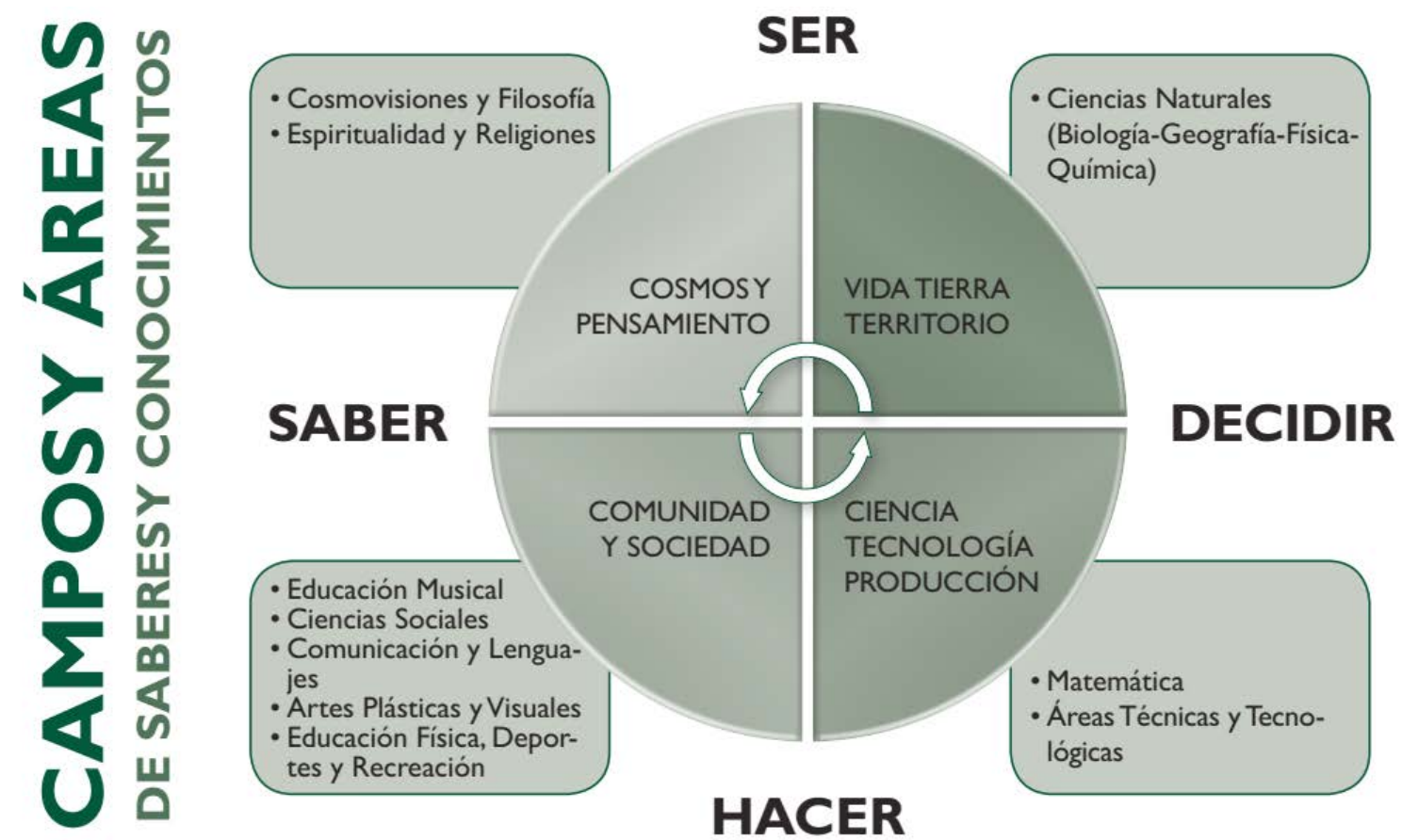

Fonte: Bolívia ([2014?], p. 23)

O currículo se estrutura ainda por meio de eixos articuladores, os quais respondem a demandas e necessidades dos povos, conforme apresentado no documento (BOLÍVIA, [2014?]). Tais eixos contribuem com a educação e com a consolidação do Estado Plurinacional e se constituem em critérios políticos que permitem dinamizar e articular os campos e áreas por meio de uma abordagem relacional de conteúdos com os fatores sociais, culturais, econômicos e políticos nos processos educativos dos subsistemas e nível de formação. Os eixos se caracterizam ainda por generalizar coerência e coesão entre os conteúdos dos campos e áreas de saberes e conhecimentos nas respectivas etapas e níveis do sistema educativo; são de aplicação obrigatória, uma vez que estão concretizados nas Temáticas Orientadoras (será discutido em parágrafo posterior), as quais são base para o desenvolvimento curricular. 
Os eixos articuladores são (BOLíVIA, [2014?]):

a) Educação Intracultural, Intercultural e Plurilíngue - constituem em elemento dinamizador e integrador dos campos e áreas de saberes e conhecimentos, a partir do fortalecimento e da reconstituição das culturas das nações e povos indígenas originários e de uma autêntica relação com as outras culturas.

b) Educação para Produção - educação criativa que recupera e aplica tecnologias próprias e pertinentes, revalorizando o trabalho manual e técnico, gerando uma produtividade com consciência responsável das necessidades, vocações e potencialidades dos contextos, que permitem a reprodução das condições de vida da comunidade e da natureza, fortalecendo a seguridade e a soberania boliviana.

c) Educação em Valores Sociocomunitários - geração de atitudes e relações de convivência que têm como centro a vida, antes dos interesses individuais. Esse critério de vida, segundo o documento (BOLÍVIA, [2014?]), podemos aprender com os povos indígenas originários a partir dos valores sociocomunitários. Tais valores na experiência de vida dos povos e nações indígenas originários são atitudes concretas que tornam possível a convivência harmônica, equilibrada, solidária e complementar na comunidade; esses valores não podem ser ensinados como conteúdos, mas sim por atitudes e práticas concretas, mediante atividades que desenvolvem nos estudantes e professores a capacidade de dar resposta aos problemas cotidianos, tendo como critério a reprodução da vida de todos antes dos interesses individuais.

d) Educação em Convivência com a Mãe Terra e Saúde Comunitária - entende-se como uma maneira de conviver e relacionar-se com a Mãe Terra; o ser humano, para reproduzir sua vida, tem que relacionar-se, conviver e compartilhar em harmonia com as diferentes formas de vida; viver com complementaridade, equilíbrio e relacionamento com a Mãe Terra por meio do despertar de uma consciência integral-holística.

Portanto, o currículo boliviano se dinamiza e constitui a partir desses quatro eixos (figura 2).

Figura 2 - Eixos articuladores

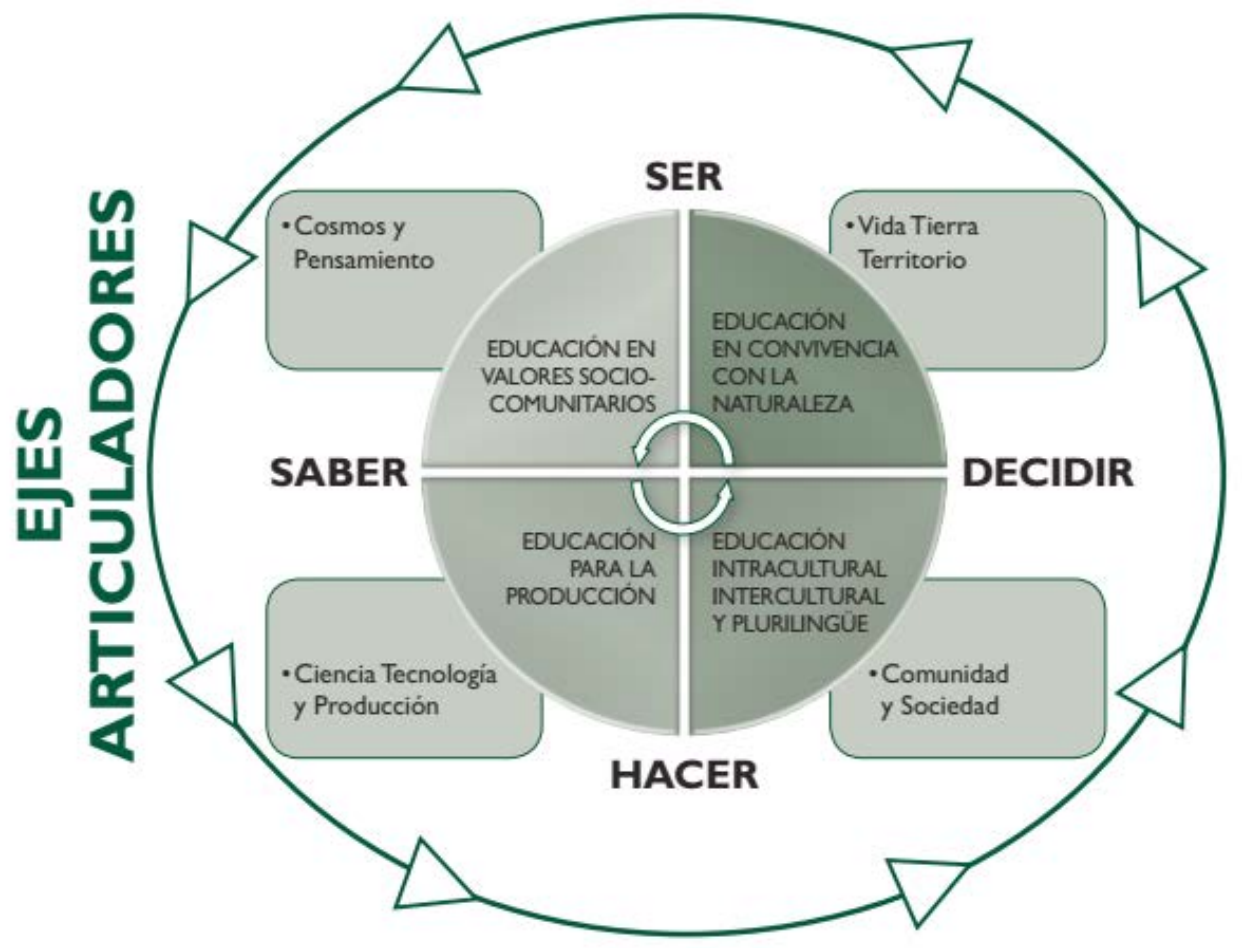

Fonte: Bolívia ([2014?], p. 28)

No currículo boliviano, os campos e áreas de saberes, os conhecimentos e os eixos articuladores geram um desenvolvimento curricular de maneira integrada, coerente e gradual, segundo as etapas e níveis de formação do sistema educativo (figura 2). Para tanto, visando evitar um trabalho fragmentado, são propostas as Temáticas Orientadoras, as quais possibilitam que os saberes e os conhecimentos 


\section{Harryson Júnior Lessa Gonçalves e Antônio Hilário Aguilera Urquiza}

sejam abordados por meio de relações complementares entre cada um deles, objetivando uma educação integral (figura 3). Tais Temáticas Orientadoras se desprendem diretamente dos eixos articuladores e se constituem como operacionais desses eixos, sendo implementadas em períodos semestrais (um por semestre), sempre permitindo que os conteúdos de cada área possam ser trabalhados de maneira sequencial e progressiva. Convertem-se em elemento curricular que articula os saberes e o conhecimento das áreas no contexto de cada campo. Portanto, necessariamente desenvolve os quatro eixos articulares: Educação Intracultural, Intercultural e Plurilíngue; Educação para Produção; Educação em Valores Sociocomunitários; Educação na Convivência com a Natureza e Saúde Comunitária (BOLÍVIA, [2014?]).

\section{Figura 3 - Temáticas orientadoras}

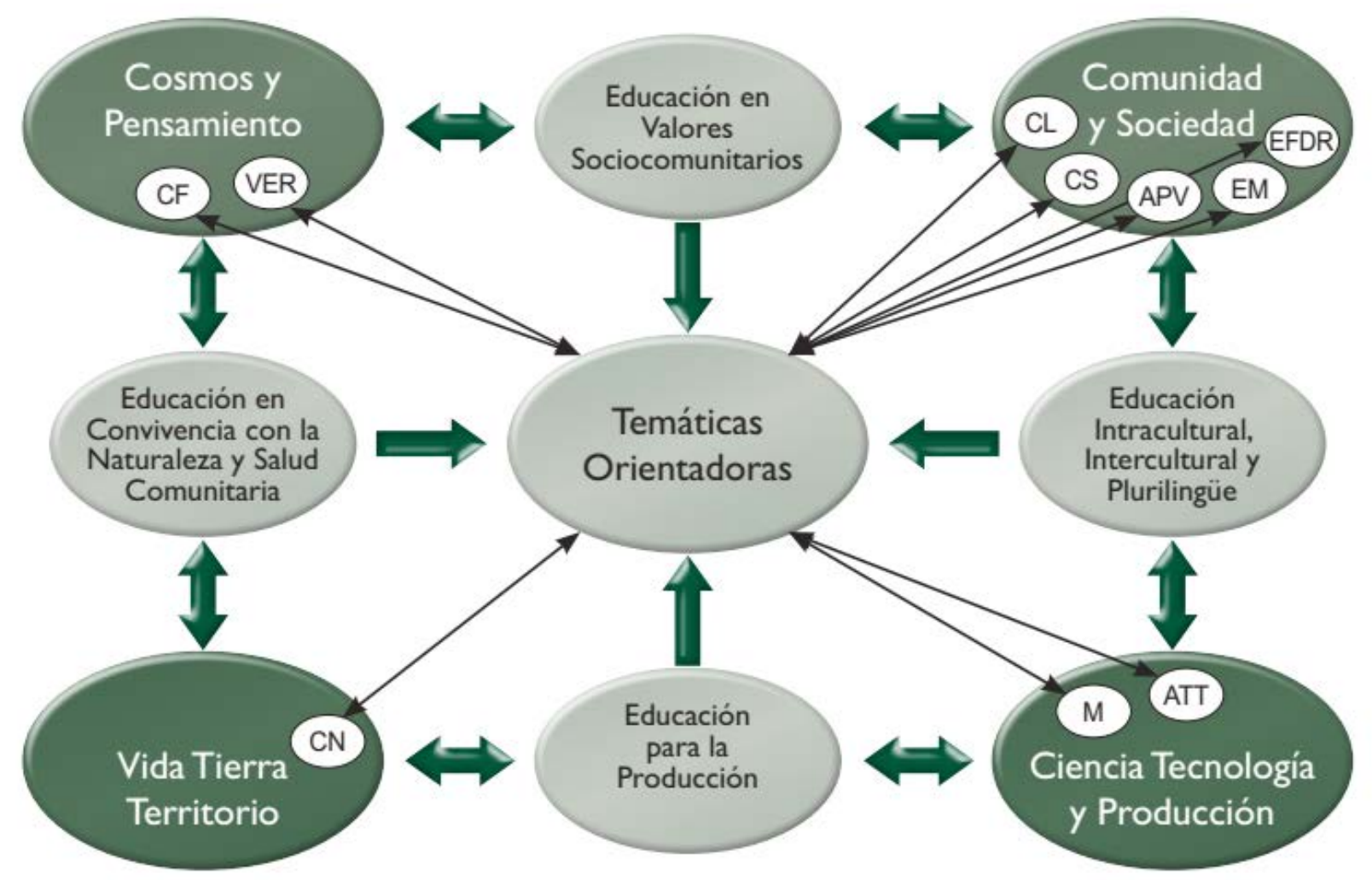

Legenda: CF: Cosmovisões e Filosofia; VER: Espiritualidade e Religiões; CL: Comunicação e Linguagens; CS: Ciências Sociais; APV: Artes Plásticas e Visuais; EM: Educação Musical; EFDR: Educação Física, Esportes e Recreação; CN: Ciências Naturais; M: Matemática; ATT: Áreas Técnicas Tecnológicas.

Fonte: Bolívia ([2014?], p. 29)

O documento (BOLÍVIA, [2014?]) evidencia, na estrutura curricular boliviana, uma relação entre os campos e áreas de saberes e conhecimentos com os eixos articuladores. Ou seja, os campos e as áreas de saberes e conhecimentos estão articulados, e o elemento que integra tais campos e eixos são as temáticas orientadoras; todavia, tais temáticas orientadoras estão definidas pelos eixos articuladores.

Entendemos que tal perspectiva possibilite uma revisão histórica, proposta por Mignolo (2003), em que o sujeito reveja aspectos que subjugaram os povos e culturas, possibilitando uma crítica à colonização e à subalternização de sua cultura colonizada fomentando a descolonização do pensamento hegemônico. Tal aspecto pode ser observado no quadro 1, quando são apresentadas as temáticas orientadoras do primeiro ano da educação secundária. 
Quadro 1 - Temáticas orientadoras $1^{\circ}$ ano da Educação Secundária

\begin{tabular}{|c|c|c|c|}
\hline Eixos Articuladores & $\begin{array}{l}\text { Temáticas } \\
\text { Orientadoras }\end{array}$ & Campos & Conteúdos das Áreas de Saberes e Conhecimentos \\
\hline \multirow[b]{2}{*}{$\begin{array}{l}\text { Educação em valores } \\
\text { sociocomunitários }\end{array}$} & \multirow{4}{*}{$\begin{array}{l}\text { Descolonização } \\
\text { e consolidação } \\
\text { sociocultural, } \\
\text { econômica e } \\
\text { tecnológica de nossos } \\
\text { povos e nações }\end{array}$} & $\begin{array}{l}\text { Cosmo e } \\
\text { Pensamento }\end{array}$ & - Valores sociocomunitários dos povos \\
\hline & & $\begin{array}{l}\text { Comunidade e } \\
\text { Sociedade }\end{array}$ & 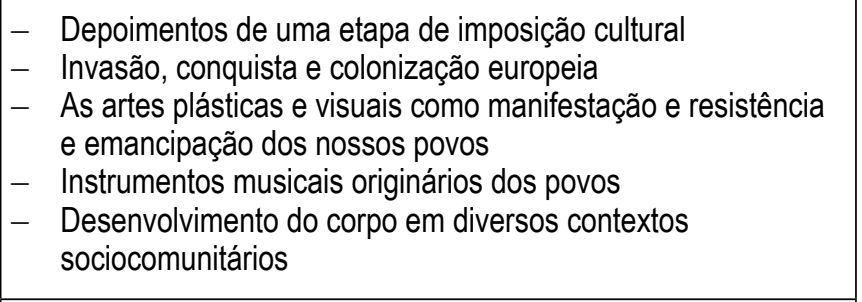 \\
\hline $\begin{array}{l}\text { Educação Intracultural, } \\
\text { Intercultural e } \\
\text { Plurilíngue }\end{array}$ & & $\begin{array}{l}\text { Vida, Terra e } \\
\text { Território }\end{array}$ & - Relação harmônica com o entorno natural e sociocomunitário \\
\hline \multirow{2}{*}{$\begin{array}{l}\text { Educação na } \\
\text { Convivência com a } \\
\text { Natureza e Saúde } \\
\text { Comunitária }\end{array}$} & & $\begin{array}{l}\text { Ciência, Tecnologia } \\
\text { e Produção }\end{array}$ & $\begin{array}{l}\text { - Polígonos irregulares na arte de nossas culturas } \\
\text { - A produção técnica e tecnológica em nossa comunidade, } \\
\text { região e país }\end{array}$ \\
\hline & \multirow{4}{*}{$\begin{array}{l}\text { Identificação } \\
\text { e análises dos } \\
\text { processos } \\
\text { socioculturais, } \\
\text { naturais e produtivos } \\
\text { do } \\
\text { Abya Yala }\end{array}$} & $\begin{array}{l}\text { Cosmo e } \\
\text { Pensamento }\end{array}$ & - Harmonia espiritual com a Mãe Terra e o Cosmo \\
\hline \multirow{3}{*}{$\begin{array}{l}\text { Educação para } \\
\text { Produção }\end{array}$} & & $\begin{array}{l}\text { Comunidade e } \\
\text { Sociedade }\end{array}$ & $\begin{array}{l}\text { - Semântica do texto em diversas línguas } \\
\text { - A sociedade comunitária e prática de valores } \\
\text { - O desenho técnico e os desenhos tecnológicos produtivos } \\
\text { - A intraculturalidade e interculturalidade cultural } \\
\text { - O esporte na integração comunitária }\end{array}$ \\
\hline & & $\begin{array}{l}\text { Vida, Terra e } \\
\text { Território }\end{array}$ & $\begin{array}{l}\text { - Os processos químicos, físicos e biológicos dos ecossistemas } \\
\text { na preservação da vida }\end{array}$ \\
\hline & & $\begin{array}{l}\text { Ciência, Tecnologia } \\
\text { e Produção }\end{array}$ & $\begin{array}{l}\text { - O pensamento lógico concreto e abstrato em diversas } \\
\text { culturas. } \\
\text { - A produção do enfoque e princípio de nossas culturas }\end{array}$ \\
\hline
\end{tabular}

Fonte: Bolívia ([2014?], p. 32-33)

Assim, no programa de estudo da Educação Secundária Comunitária Produtiva (BOLIVIA, 2012a), a Matemática visa a recuperar, fortalecer e valorizar os saberes matemáticos dos povos bolivianos, que são parte intrínseca da vivência diária do ser humano no seu entorno natural. Assim, a Matemática, nessa perspectiva, desenvolve o pensamento lógico concreto e abstrato e as capacidades crítica e reflexiva da realidade, apoiando as áreas tecnológicas produtivas.

O documento aponta ainda que a Educação Matemática gera espaços para que os estudantes encontrem soluções para as necessidades da comunidade a partir das próprias interpretações, inferências lógicas, modelos, projetos e a investigação, recuperando assim o saber matemático das culturas dos povos bolivianos que se aplicam no fazer cotidiano, com o espírito de desencadear a complexidade das dimensões do ser humano: Ser, Saber, Fazer e Decidir. Assim, acreditamos tal entendimento possibilite o pensamento descolonial que, conforme Mignolo (2008, p. 249), proporcione "[...] pensa a partir das margens, e pensa as margens em relações imperiais-coloniais de poder. A descolonização da história narrada e do pensamento historiográfico é parte da tarefa do pensamento descolonial para avançar na opção descolonial".

Tal possibilidade pode ser corroborada ainda quando o currículo discorre sobre o caráter da matemática:

a) Investigativo - porque se constitui em um componente dinamizador dos saberes e conhecimentos matemáticos, desenvolvendo o pensamento matemático que permite conviver e coordenar ações em situações complexas do entorno priorizando a recuperação e aplicação de saberes matemáticos desenvolvidos pela cultura dos povos e nações ao 
longo da história da atividade produtiva do contexto sociocultural boliviano, possibilitando a compreensão da natureza.

b) Aplicativo - porque orienta a aplicação da Matemática na atividade produtiva em comparação com outras áreas, por meio de projetos socioprodutivos visando o bem comum.

c) Transformador - porque integra a aplicação-investigação da Matemática, transformando a realidade para satisfazer as necessidades da sociedade em comunidade, desenvolvendo por meio de empreendimentos produtivos. A Educação Matemática se desenvolve a partir do pensamento multidimensional integrado à vida, respondendo às necessidades e potencialidades da comunidade, tomando como fonte de formação dos fenômenos sociais e naturais que possibilitam a mudança da realidade boliviana.

No primeiro ano da Educação Secundária Comunitária Produtiva, a Matemática tem como objetivo desenvolver o pensamento lógico-matemático crítico e reflexivo, na vida, para a vida e na diversidade cultural mediante a Educação Matemática, a percepção e apreensão do espaço geométrico, formas, números e operações, letras, símbolos, medidas e cálculo, para contribuir com o desenvolvimento do sistema produtivo tecnológico e social (BOLÍVIA, 2012a). Nos anexos (Ae B) são apresentados os quadros referentes à planificação curricular de Matemática para o primeiro ano da Educação Secundária Comunitária Produtiva.

O documento aponta ainda as seguintes estratégias para o desenvolvimento curricular em Matemática:

a) Trabalho social comunitário - a Matemática, adotará e adequará formas de trabalho comunitário do centro educativo ou da comunidade por meio de equipes de trabalho, círculos de discussão em projetos socioprodutivos, a fim de implementar e/ou impulsionar férias educativas, resgate da riqueza cultural, acontecimento artístico, espaços recreativos de empreendimentos, cuidado e defesa dos recursos naturais e outros de interesses social e educativo. O trabalho social comunitário contribuirá também como o intercâmbio de experiências, aprender uns com os outros, fortalecer a solidariedade, reciprocidade e complementaridade e o desenvolvimento do espírito de sensibilidade social na convivência comunitária.

b) Experiência acumulada - a experiência deve ser a basilar para a aprendizagem de novos conhecimentos e práticas; ou seja, aprender da vida em si e do contexto sociocomunitário.

c) Investigação participativa - deve ser eminentemente participativa e comprometida com a comunidade, o grupo social ou o conjunto de estudantes, em que todos devem buscar a solução para os problemas planejados, a aquisição de novos conhecimentos ou o aporte para transformação da realidade social, econômica e política. Assim, canalizará suas ações para gerar novos saberes e conhecimentos da realidade circundante, bem como melhorará as condições de vida da comunidade e fortalecerá a autoestima e a identidade cultural.

Tais estratégias apontam para um posicionamento identitários boliviano atrelado a um sistema de representações com a utilização dos recursos da linguagem, história e cultura - consonante com Hall (2000, p. 109).

[…] tem a ver não tanto com as questões 'quem nós somos' ou 'de onde nós viemos', mas muito mais com as questões 'quem podemos nos tornar', 'como nós temos sido representados' e como essa representação afeta a forma como nós podemos representar anos próprios.

O documento (BOLÍVIA, 2012a) propõe que os objetivos da área de Matemática contemplam as dimensões: Ser, Fazer, Saber e Decidir, e se integram, ciclicamente, aos processos educativos com as diferentes áreas produtivas, tomando como referência as estratégias metodológicas em continuação na figura 4 . 
Figura 4 - Estratégias metodológicas

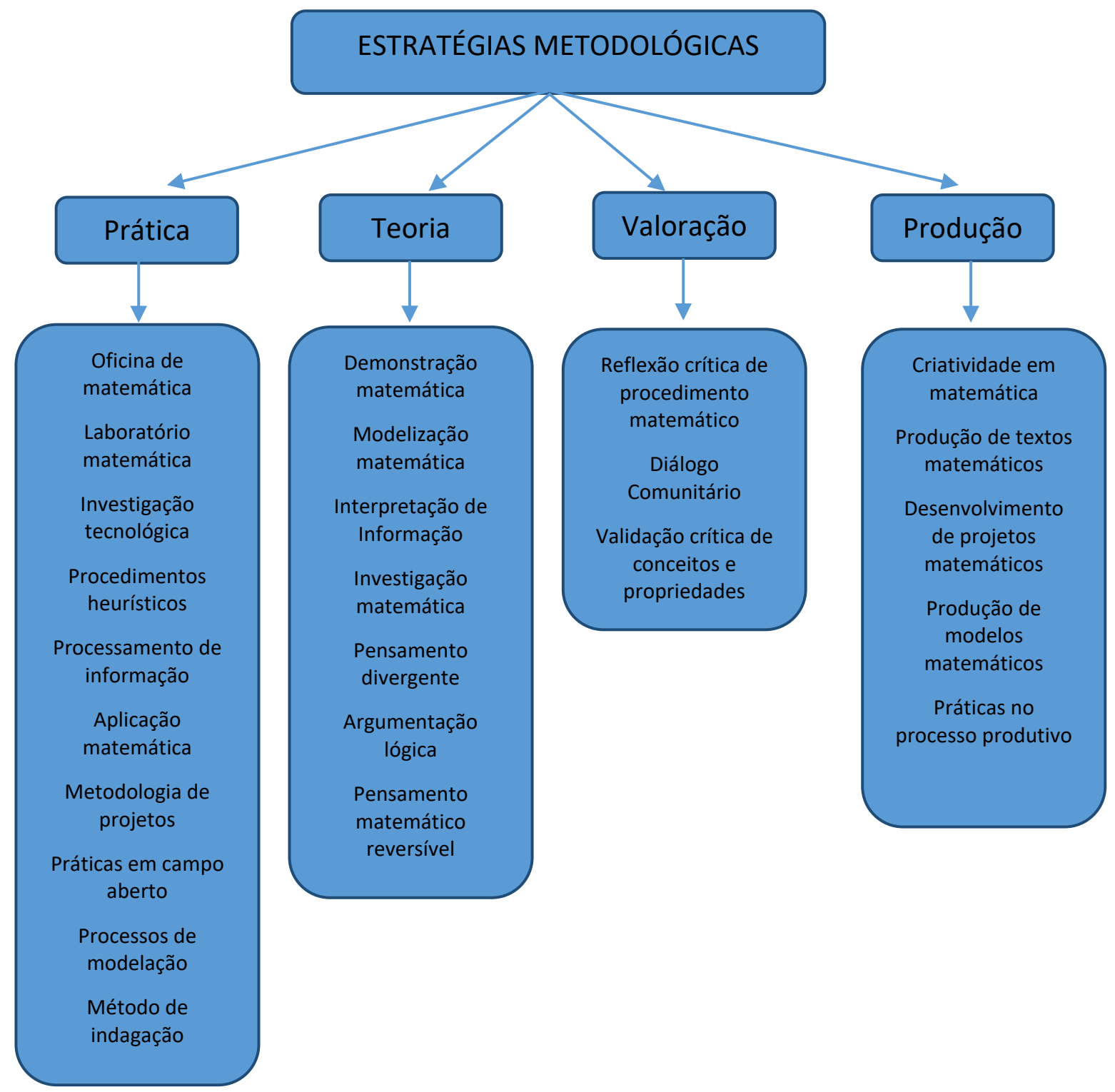

Fonte: Bolívia (2012a, p. 126)

No tocante à avaliação em Matemática, o currículo (BOLÍVIA, 2012a) propõe que seja qualitativa e quantitativa permanente, cíclica e processual, que leve em conta a participação dos que estão envolvidos no processo educativo. A avaliação serve de referência para detectar realizações e falhas existentes, visando estabelecer estratégias que permitam superar as dificuldades, atribuir os êxitos alcançados e garantir a integridade da formação do ser humano. A avaliação responde os seguintes critérios: permanente (acontece durante todo o processo educativo e em momentos distintos); integral e holística (envolve a realidade social, espiritual, cultural, econômica, política e ideológica de cada contexto e das condições particulares dos participantes do processo educativo); sistemática (aplica-se com a inter-relação e coerência dos elementos curriculares no desenvolvimento da ação educativa); comunitária (leva em conta todos os atores envolvidos no processo) e dialógica (desenvolve-se em permanente relação com as distintas ações que se manifestam entre as pessoas envolvidas).

\section{CONSIDERAÇÕES FINAIS}

A Bolívia, em seu processo de implementação da Lei "Avelino Siñani - Elizardo Pérez" (Lei da Educação $n^{\circ}$ 070/2010), mobiliza ações no processo de planificação/implementação curricular, envolvendo, a partir dos documentos analisados, os diversos atores envolvidos no processo educativo e propondo um sistema educacional que promova uma Educação Intracultural, Intercultural 
e Plurilíngue, promotora de uma educação que contribua com a descolonização do povo boliviano, bem como o desenvolvimento social e econômico do Estado Plurinacional da Bolívia.

O currículo analisado nos revelou um compromisso com a educação centrada em aspectos antropológicos que toma o conhecimento como histórica e socialmente posicionado a partir da diversidade cultural, valorizando, assim, saberes providos de povos originários. Para tanto, consubstancia tal construção curricular em perspectivas teóricas de autores pós-coloniais. Para tanto, problematiza, a partir de aspectos culturais e identitários, o processo de colonização do povo boliviano em uma busca de pensamento descolonizado.

Nos currículos analisados não foram percebidas referências às bases teóricas legitimadas, em geral, pela comunidade internacional de educadores matemáticos sobre o Ensino de Matemática - por exemplo, a Etnomatemática (D’AMBROSIO, 2005) e a Sócio epistemologia (CANTORAL; MONTIEL; REYES-GASPERINI, 2015). Inclusive, Grigoriu (2014) afirma que poucas ações têm sido desenvolvidas pela Soboedma junto aos professores bolivianos em razão do processo obrigatório de formação contínua do Estado (Profocom). "A partir desse ano [2009] não podemos voltar a nos reunirmos porque os professores se comprometeram com a formação no Programa de Formação Contínua de Professores em Exercício (Profocom) que o governo impulsa de forma obrigatória" (GRIGORIU, 2014, p. 28, tradução nossa)

Talvez tal escassez de referências esteja relacionada a uma iminência de se constituir um paradigma teórico que emerja da realidade cultural dos povos bolivianos, constituída a partir de sua diversidade cultural que afirme aspectos identitários de povos originários.

Quanto ao currículo da Matemática, constatamos que esta tem como proposta recuperar, fortalecer e valorizar os saberes matemáticos dos povos bolivianos, que são parte intrínseca da vivência diária do ser humano no seu entorno natural. A Matemática, nessa perspectiva, desenvolve o pensamento lógico concreto e abstrato e as capacidades crítica e reflexiva da realidade, apoiando as áreas tecnológicas produtivas. Por outro lado, essa mesma Educação Matemática gera espaços para que os estudantes encontrem soluções para as necessidades da comunidade a partir das próprias interpretações, inferências lógicas, modelos, projetos e a investigação, recuperando assim o saber matemático das culturas dos povos bolivianos que se aplicam no fazer cotidiano, com o espírito de desencadear a complexidade das dimensões do ser humano: Ser, Saber, Fazer e Decidir.

Acreditamos, assim, que tal entendimento possibilite o pensamento descolonial o qual, "[...] pensa a partir das margens, e pensa as margens em relações imperiais-coloniais de poder. A descolonização da história narrada e do pensamento historiográfico é parte da tarefa do pensamento descolonial para avançar na opção descolonial" (MIGNOLO, 2008, p. 249).

A partir deste trabalho, concluímos que investigações (em campo) tornam-se urgentes e necessárias visando identificar os mecanismos e processos que permeiam a construção curricular na Bolívia no âmbito dos diversos intervenientes do currículo - currículo prescrito, praticado, moldado/modelado, apresentado, avaliado. E, assim, compreender processos de planificação/ implementação curricular que rompam com paradigmas hegemônicos - em geral - norteados por políticas estrangeiras (estadunidenses e europeias) concretizadas em avaliações em larga escala. 


\section{REFERÊNCIAS}

AYERBE, L. F. Crise de hegemonia e emergência de novos atores na Bolívia: o governo de Evo Morales. Lua Nova, São Paulo, n. 83, p. 179-216, 2011. Disponível em: <http://goo.gl/y6YsuX>. Acesso em: 12 mar. 2017.

BOLÍVIA. Educación secundaria comunitaria productiva: programa de estudio - primer año. La Paz: Ministerio de Educación, 2012a.

Estrategias de desarrollo curricular socioproductivo: comprendiendo la estructura curricular. La Paz: Ministerio de Educación, [2014?].

Instituto Nacional de Estadística. Educación. La Paz, 2012b. Disponível em: <http://www.ine. gob.bo/>. Acesso em: 12 mar. 2017.

Ley de la Educación $n^{\circ}$ 070: "Avelino Siñani - Elizardo Pérez". La Paz: Ministerio de Educación, 2010. Disponível em: <https://goo.gl/6QKJQs>. Acesso em: 12 mar. 2017.

Plan de desarrollo económico y social 2016-2020: en el marco del desarrollo integral para vivir bien. La Paz: Ministerio de Planificación del Desarrollo, [2015?]. Disponível em: <http://www.planificacion.gob.bo/pdes/>. Acesso em: 12 mar. 2017.

BRASIL. Constituição (1988). Constituição da República Federativa do Brasil. Brasília, DF: Senado Federal, 1988.

CALDERONI, V. A. M. de O. Desconstruindo preconceitos sobre os povos indígenas: módulo $\mathrm{V}$ do curso de especialização em antropologia e história dos povos indígenas. Campo Grande: UFMS, 2016.

CANTORAL, R.; MONTIEL, G.; REYES-GASPERI$\mathrm{NI}$, D. El programa socioepistemológico de investigación en Matemática Educativa: el caso de Latinoamérica. Relime, México, v. 18, n. 1, p. 5-17, mar. 2015. Disponível em: <https://goo.gl/bNJCER>. Acesso em: 12 mar. 2017.

D'AMBROSIO, U. Sociedade, cultura, matemática e seu ensino. Educação e pesquisa, São Paulo, v. 1, n. 31, p. 99-120, jan./abr. 2005. Disponível em: <http://www.scielo.br/pdf/ep/v31n1/a08v31n1.pdf>. Acesso em: 13 mar. 2017.
GRIGORIU, B. Sistemas educativos: la educación matemática en Bolivia. Unión, n. 1, p. 55-88, 2005. Disponível em: <https://goo.gl/9yHsJl>. Acesso em: 12 mar. 2017.

Soboedma: sociedad boliviana de educación matemática. Unión, n. 40, p. 25-31, 2014. Disponível em: <https://goo.gl/DOOcrt>. Acesso em: 12 mar. 2017.

HALL, S. Quem precisa da identidade? In: SILVA, T. T. da (Org.). Identidade e diferença: a perspectiva dos estudos culturais. Petrópolis: Editora Vozes, 2000. p. 103-133.

KLEIN, H. S. Bolívia: do período pré-incaico à independência. São Paulo: Brasiliense, 2004.

MIGNOLO, W. Desobediencia epistémica: retórica de la modernidad, lógica de la colonialidad y gramática de la descolonialidad. Buenos Aires: Ediciones del Signo, 2010.

Histórias locais/projetos globais: colonialidade, saberes subalternos e pensamento liminar. Belo Horizonte: Editora UFMG, 2003.

Novas reflexões sobre a "idéia da América Latina": a direita, a esquerda e a opção descolonial. Cad. CRH, Salvador, v. 21, n. 53, p. 237-250, ago. 2008. Disponível em: <https://goo.gl/ZVGgia>. Acesso em: 12 mar. 2017.

PIRES, C. M. C.; GONÇALVES, H. J. L. Aspectos conceituais e epistemológicos da educação comparada presentes no projeto "Pesquisas comparativas sobre organização e desenvolvimento curricular na área de Educação Matemática, em países da América Latina". Perspectivas da Educação Matemática, Campo Grande, v. 8, n. 18, p. 396-414, set./dez. 2015. Quadrimestral.

QUIJANO, A. Colonialidad del poder y clasificación social. Journal of World-Systems Research, v. 11, n. 2, p. 342-386, 2000.

SILVA, T. T. Documentos de identidade: uma introdução às teorias do currículo. Belo Horizonte: Autêntica, 2007. 


\section{Anexo A - Primeiro Ano de Educação Secundária Comunitária Produtiva (Primeira Fase Área: Matemática)}

\begin{tabular}{|c|c|c|c|c|c|}
\hline \multicolumn{6}{|c|}{ Temática Orientadora: Descolonização e consolidação sociocultural, econômica e tecnológica } \\
\hline DIMENSÕES & $\begin{array}{l}\text { OBJETIVOS } \\
\text { HOLISTICOS }\end{array}$ & $\begin{array}{l}\text { CONTEÚDOS E EIXOS } \\
\text { ARTICULADORES }\end{array}$ & ORIENTAÇÕES METODOLÓGICAS & AVALIAÇÃO & PRODUTOS \\
\hline Ser & \multirow{4}{*}{$\begin{array}{l}\text { Fortalecermos } \\
\text { as relações } \\
\text { interpessoais dos } \\
\text { estudantes através } \\
\text { do estudo de } \\
\text { arte e tecnologia, } \\
\text { identificando formas } \\
\text { poligonais e suas } \\
\text { propriedades, } \\
\text { mediante } \\
\text { procedimentos } \\
\text { e operações de } \\
\text { perímetros e áreas, } \\
\text { para contribuir } \\
\text { e recuperar o } \\
\text { desenvolvimento da } \\
\text { produção, tecnologia } \\
\text { e sociedade }\end{array}$} & \multirow{4}{*}{$\begin{array}{l}\text { Polígonos irregulares na arte de } \\
\text { nossas culturas } \\
\text { - Losango: diagonais, } \\
\text { perímetros, aplicados na arte } \\
\text { das culturas } \\
\text { - Trapézio: classes, diagonais, } \\
\text { perímetros e área na } \\
\text { tecnologia. }\end{array}$} & \multirow{4}{*}{$\begin{array}{l}\text { - Observação e reconhecimento de polígonos no } \\
\text { espaço do entorno. } \\
\text { - Oficina de geometria, utilizando materiais } \\
\text { concretos, para representar polígonos irregulares } \\
\text { com a ajuda dos assistentes matemáticos, para } \\
\text { facilitar a compreensão. } \\
\text { - Aplicação dos polígonos irregulares em espaços } \\
\text { abertos, utilizando perimetros e áreas, em } \\
\text { interação com o trabalho comunitário. } \\
\text { - Comparação e análises de propriedades dos } \\
\text { losangos e trapézios, utilizando instrumentos de } \\
\text { medição em espaços de produção. } \\
\text { - Reflexão e crítica da importância dos losangos } \\
\text { e trapézios e suas operações em situações } \\
\text { concretas das necessidades da comunidade. } \\
\text { - Construção de produtos tecnológicos em } \\
\text { complementaridade com os saberes de nossos } \\
\text { antepassados e a diversidade de outras culturas. }\end{array}$} & $\begin{array}{l}\text { - Valoração de expressões culturais } \\
\text { próprias em relação às noções } \\
\text { geométricas, aritméticas e estatísticas. }\end{array}$ & \multirow{4}{*}{$\begin{array}{l}\text { Produtos tecnológicos } \\
\text { elaborados, utilizando os } \\
\text { polígonos, recuperando os } \\
\text { saberes do nosso povo. }\end{array}$} \\
\hline Saber & & & & $\begin{array}{l}\text { - Identificação e classificação de figuras } \\
\text { planas e seus elementos relacionados } \\
\text { com o entorno natural. } \\
\text { - Capacidade de análises das operações } \\
\text { em situações concretas. }\end{array}$ & \\
\hline \multirow[b]{2}{*}{ Decidir } & & & & $\begin{array}{l}\text { - Aplicação dos números naturais, } \\
\text { inteiros e racionais, respondendo } \\
\text { as necessidades produtivas e } \\
\text { tecnológicas da comunidade. } \\
\text { - Aporte crítico nas atividades produtivas } \\
\text { da comunidade por meio da aplicação } \\
\text { das diferentes formas poligonais e os } \\
\text { conjuntos numéricos. }\end{array}$ & \\
\hline & & & & $\begin{array}{l}\text { - Assume critérios reflexivos acerca da } \\
\text { utilização dos polígonos e números } \\
\text { inteiros nas necessidades produtivas e } \\
\text { tecnológicas da comunidade. }\end{array}$ & \\
\hline Ser & \multirow{4}{*}{$\begin{array}{l}\text { Desenvolvermos o } \\
\text { diálogo intercultural, } \\
\text { analisando } \\
\text { propriedades } \\
\text { e concepções } \\
\text { dos números e } \\
\text { operações, aplicando } \\
\text { procedimentos } \\
\text { algorítmicos e } \\
\text { heurísticos, para } \\
\text { responder as } \\
\text { necessidades } \\
\text { produtivas e } \\
\text { tecnológicas da } \\
\text { comunidade. }\end{array}$} & \multirow{4}{*}{$\begin{array}{l}\text { Sistemas de numeração e } \\
\text { conjuntos numéricos } \\
\text { - Sistemas de numeração nas } \\
\text { distintas culturas. } \\
\text { - Origem dos números naturais, } \\
\text { inteiros e sua utilidade na vida } \\
\text { cotidiana. } \\
\text { - Operações de números inteiros } \\
\text { e sua aplicação no econômico } \\
\text { produtivo, social e sociedade. } \\
\text { - Potencialização e radiciação } \\
\text { de números inteiros e sua } \\
\text { aplicação nas ciências. } \\
\text { - Representação concreta e } \\
\text { abstrata de números racionais } \\
\text { e suas formas de quantificar. } \\
\text { - Relação de ordem dos } \\
\text { números racionais. } \\
\text { - Números racionais e sua } \\
\text { aplicação na economia } \\
\text { - produção, sociedade e } \\
\text { tecnologia. } \\
\text { - Operações dos números } \\
\text { racionais e suas propriedades. }\end{array}$} & \multirow{4}{*}{$\begin{array}{l}\text { - Indagação de práticas e experiências cotidianas } \\
\text { com relação aos sistemas de numeração. } \\
\\
\text { - Aplicação de conceitos e propriedades dos } \\
\text { números naturais, inteiros e racionais em } \\
\text { situações concretas, relacionando saberes intra e } \\
\text { interculturais em grupos comunitários. }\end{array}$} & $\begin{array}{l}\text { - Valoração de expressões culturais } \\
\text { próprias em relação às noções } \\
\text { geométricas, aritméticas e estatísticas. }\end{array}$ & \multirow[b]{4}{*}{$\begin{array}{l}\text { Artigos escritos, referentes } \\
\text { aos sistemas numéricos das } \\
\text { diferentes culturas. }\end{array}$} \\
\hline Saber & & & & $\begin{array}{l}\text { Reconhecimento das características e } \\
\text { propriedades dos números naturais, } \\
\text { inteiros e racionais. }\end{array}$ & \\
\hline Fazer & & & & $\begin{array}{l}\text { - Manejo e uso apropriado das } \\
\text { propriedades de polígonos irregulares } \\
\text { e números inteiros em atividades } \\
\text { sociocomunitárias. }\end{array}$ & \\
\hline Decidir & & & & $\begin{array}{l}\text { - Assume critérios reflexivos acerca da } \\
\text { utilização dos poligonos e números } \\
\text { inteiros nas necessidades produtivas e } \\
\text { tecnológicas da comunidade. }\end{array}$ & \\
\hline Ser & \multirow{4}{*}{$\begin{array}{l}\text { Compreendermos a } \\
\text { informação estatística } \\
\text { por meio de } \\
\text { atividades concretas } \\
\text { no marco das } \\
\text { reações comunitárias } \\
\text { e de consenso para } \\
\text { a produção do saber } \\
\text { matemático produtivo } \\
\text { e tecnológico. }\end{array}$} & \multirow{4}{*}{$\begin{array}{l}\text { Levantamento de dados } \\
\text { estatísticos nos processos } \\
\text { produtivos e sociais }\end{array}$} & \multirow{4}{*}{$\begin{array}{l}\text { - Indagação sobre as formas ou maneiras de } \\
\text { quantificar os processos produtivos e sociais } \\
\text { existentes na comunidade. } \\
\text { - Captação de dados das potencialidades e } \\
\text { vocações, utilizando instrumentos estatísticos. } \\
\text { - Análises de dados dos processos produtivos da } \\
\text { região. } \\
\text { - Conceptualização da estatística por meio da } \\
\text { revisão bibliográfica em grupos comunitários. } \\
\text { - Reflexão sobre o manejo transparente dos } \\
\text { recursos e bens socioeconômicos por meio do } \\
\text { processamento de dados estatísticos. } \\
\text { - Planificação de propostas alternativas que } \\
\text { busquem o equilíbrio na produção e distribuição } \\
\text { de bens e serviços. }\end{array}$} & $\begin{array}{l}\text { - Valoração de expressões culturais } \\
\text { próprias em relação às noções } \\
\text { geométricas, aritméticas e estatísticas. }\end{array}$ & \multirow{4}{*}{$\begin{array}{l}\text { Informe quantitativo das } \\
\text { potencialidades e vocações } \\
\text { produtivas da comunidade. }\end{array}$} \\
\hline Saber & & & & $\begin{array}{l}\text { - Interpretação de dados estatísticos em } \\
\text { tabelas e gráficos. }\end{array}$ & \\
\hline Fazer & & & & $\begin{array}{l}\text { - Construção de tabelas e gráficos } \\
\text { estatísticos. }\end{array}$ & \\
\hline Decidir & & & & $\begin{array}{l}\text { - Propor e aplicar critérios estatísticos } \\
\text { para melhorar a produção em sua } \\
\text { comunidade focando na qualidade } \\
\text { de vida. }\end{array}$ & \\
\hline
\end{tabular}

Fonte: Bolívia (2012a). 


\section{Anexo B - Primeiro Ano de Educação Secundária Comunitária Produtiva (Segunda Fase Área: Matemática)}

\begin{tabular}{|c|c|c|c|c|c|}
\hline DIMENSÕES & OBJETIVOS HOLÍSTICOS & $\begin{array}{l}\text { CONTEÚDOS E EIXOS } \\
\text { ARTICULADORES }\end{array}$ & ORIENTAÇÕES METODOLÓGICAS & AVALIAÇÃO & PRODUTOS \\
\hline Ser & \multirow{4}{*}{$\begin{array}{l}\text { - Desenvolvermos } \\
\text { atitude de respeito } \\
\text { em convivência } \\
\text { harmônica com a } \\
\text { natureza, estudando } \\
\text { as figuras geométricas } \\
\text { poligonais por meio de } \\
\text { procedimentos de cálculo } \\
\text { de áreas e perímetros } \\
\text { no entorno natural, } \\
\text { para contribuir com os } \\
\text { processos de produção } \\
\text { da comunidade. } \\
\text { - O círculo, a circunferência } \\
\text { e seus elementos na } \\
\text { tecnologia. } \\
\text { - O valor de "m" e os } \\
\text { saberes matemáticos } \\
\text { ancestrais. }\end{array}$} & \multirow[t]{4}{*}{$\begin{array}{l}\text { A geometria e suas relações } \\
\text { com o entorno natural e } \\
\text { cultural }\end{array}$} & \multirow{4}{*}{$\begin{array}{l}\text { - Observação de elementos geométricos } \\
\text { presentes na natureza e em situações } \\
\text { concretas da comunidade. } \\
\text { - Elaboração de figuras geométricas com o } \\
\text { uso de diversos instrumentos e materiais } \\
\text { concretos e tecnológicos do lugar. } \\
\text { - Comparação e análises das propriedades } \\
\text { de polígonos e circunferências com } \\
\text { relação aos elementos geométricos de } \\
\text { seu entorno, utilizando instrumentos de } \\
\text { medição dos saberes dos povos. } \\
\text { - Determinação de perímetros, áreas de } \\
\text { polígonos aplicando números e símbolos } \\
\text { em problemas da comunidade. } \\
\text { - Elaboração de projetos socioprodutivos, } \\
\text { a partir de visitas de estudos em campo } \\
\text { de produção. } \\
\text { - Construção de polígonos, interpretando e } \\
\text { usando as relações ou conceitos para o } \\
\text { cálculo de perimetros e áreas. } \\
\text { - Exposição e elaboração de geoplanos e } \\
\text { outros materiais educativos para estudar } \\
\text { as formas poligonais e a compreensão do } \\
\text { número PI. } \\
\text { - Triângulos semelhantes na tecnologia de } \\
\text { estruturas fixas e na produção. }\end{array}$} & $\begin{array}{l}\text { - Valoração do saber geométrico de } \\
\text { nossas culturas, suas propriedades } \\
\text { de polígonos e circunferências. } \\
\text { - Reflexão sobre a importância dos } \\
\text { números no desenvolvimento de } \\
\text { nossos povos. }\end{array}$ & \multirow{4}{*}{$\begin{array}{l}\text { Manejo e aplicação de } \\
\text { conceitos, definições } \\
\text { e propriedades } \\
\text { de polígonos e } \\
\text { circunferência na } \\
\text { implementação de } \\
\text { projetos produtivos } \\
\text { ou tecnológicos } \\
\text { para beneficiar a } \\
\text { comunidade e o } \\
\text { cuidado da natureza. }\end{array}$} \\
\hline Saber & & & & $\begin{array}{l}\text { - Interpretação e uso de relações } \\
\text { para o cálculo de perímetros e } \\
\text { áreas. } \\
\text { - Comparação dos números naturais } \\
\text { e inteiros, com ajuda da reta } \\
\text { numérica. } \\
\text { - Interpretação de dados, } \\
\text { compreensão e quantificação dos } \\
\text { recursos naturais. }\end{array}$ & \\
\hline Fazer & & & & $\begin{array}{l}\text { Elaboração de recursos didáticos } \\
\text { e sua aplicação na tecnologia, } \\
\text { aplicando as semelhanças e } \\
\text { propriedades dos triângulos. } \\
\end{array}$ & \\
\hline Decidir & & & & $\begin{array}{l}\text { - Apropriação de habilidades e } \\
\text { destrezas para aplicar conceitos } \\
\text { de polígonos em produtos } \\
\text { tecnológicos e da produção, } \\
\text { segundo as necessidades da } \\
\text { comunidade. } \\
\text { Decisões sobre certas regras } \\
\text { em procedimentos heurísticos, } \\
\text { aplicando razões e proporções na } \\
\text { situação ou problema do contexto. }\end{array}$ & \\
\hline Ser & \multirow{4}{*}{\begin{tabular}{|l|} 
Desenvolvermos o \\
pensamento lógico, \\
concreto e abstrato de \\
propriedades, conceitos e \\
sua relação com a álgebra, \\
por meio de procedimentos \\
e regras operatórias, \\
valorando as expressões \\
simbólicas das nossas \\
culturas, para promover \\
e revalorizar os saberes \\
matemáticos.
\end{tabular}} & \multirow{4}{*}{$\begin{array}{l}\text { O pensamento lógico concreto } \\
\text { e abstrato as diversas culturas } \\
\text { - Operações de números } \\
\text { racionais, suas propriedades } \\
\text { e suas combinações } \\
\text { aplicadas nas atividades } \\
\text { comerciais, produtivas e } \\
\text { sociais. } \\
\text { - Razões e proporções na } \\
\text { distribuição equitativa } \\
\text { de bens e serviços da } \\
\text { comunidade. } \\
\text { - Regra de três simples } \\
\text { e composta no manejo } \\
\text { estratégico dos recursos } \\
\text { naturais e econômico da } \\
\text { comunidade. } \\
\text { - Noções de álgebra nas } \\
\text { atividades sociais, produtivas } \\
\text { e de aplicação na ciência e } \\
\text { tecnologia, assim como na } \\
\text { sua relação com a natureza. }\end{array}$} & \multirow{4}{*}{$\begin{array}{l}\text { - Investigação sobre as expressões } \\
\text { simbólicas de nossas culturas, realizando } \\
\text { visitas a museus, viagens de estudos e } \\
\text { outros. } \\
\text { - Aplicação de propriedades de números } \\
\text { racionais em situações concretas da vida. } \\
\text { - Aplicação de razões, proporções e noções } \\
\text { de álgebra em vivências e necessidades } \\
\text { socioeconômicas comunitárias. } \\
\text { - Análises de números racionais, razões, } \\
\text { proporções e noções de álgebra aplicadas } \\
\text { nas atividades comerciais, produtivas, } \\
\text { sociais e de aplicação na ciência e } \\
\text { tecnologia. } \\
\text { - Diálogos e reflexões sobre a importância } \\
\text { de números racionais, rações, proporções } \\
\text { e noções de álgebra recuperando saberes } \\
\text { de nossas culturas. } \\
\text { - Publicação de textos e outras } \\
\text { representações que mostrem os } \\
\text { fenômenos sociais e naturais da região } \\
\text { por meio de quadros e como resultado de } \\
\text { processos de investigação. }\end{array}$} & $\begin{array}{l}\text { Relação de propriedades e } \\
\text { conceitos de aritmética com a } \\
\text { álgebra no desenvolvimento de } \\
\text { pensamento lógico, concreto e } \\
\text { abstrato. }\end{array}$ & \multirow{4}{*}{$\begin{array}{l}\text { Objetos concretos } \\
\text { construídos a partir dos } \\
\text { números racionais e } \\
\text { expressões algébricas } \\
\text { apresentados em } \\
\text { espaços socioculturais } \\
\text { ou produtivos. }\end{array}$} \\
\hline Saber & & & & $\begin{array}{l}\text { - Aplicação de conceitos e } \\
\text { propriedades com procedimentos e } \\
\text { regras operatórias na resolução de } \\
\text { problemas de seu entorno. }\end{array}$ & \\
\hline Fazer & & & & $\begin{array}{l}\text { Valoração e apropriação das } \\
\text { expressões simbólicas de nossas } \\
\text { culturas. }\end{array}$ & \\
\hline Decidir & & & & $\begin{array}{l}\text { - Apresentação de recursos didáticos } \\
\text { e textos que mostrem fenômenos } \\
\text { sociais e naturais da região. }\end{array}$ & \\
\hline Ser & \multirow{4}{*}{$\begin{array}{l}\text { Desenvolvermos hábitos } \\
\text { de transparência e } \\
\text { responsabilidade de } \\
\text { manejo econômico por } \\
\text { meio dos registros e } \\
\text { documentos contábeis para } \\
\text { contribuir com a atividade } \\
\text { socioeconômica. }\end{array}$} & \multirow{4}{*}{$\begin{array}{l}\text { A matemática e atividades } \\
\text { econômico-financeiras } \\
\text { - Contabilidade básica } \\
\text { das atividades sociais, } \\
\text { comerciais e produtivas da } \\
\text { vida diária. } \\
\text { - Registros básicos e } \\
\text { documentos contábeis na } \\
\text { administração de nossos } \\
\text { recursos. }\end{array}$} & \multirow{4}{*}{$\begin{array}{l}\text { - Indagação, análises e elaboração de } \\
\text { registros contábeis básicos sobre os } \\
\text { recursos que se encontram na família, } \\
\text { escola, comunidade e outras atividades de } \\
\text { caráter produtivo. } \\
\text { - Identificação e diferenciação de } \\
\text { documentos contábeis, em equipe de } \\
\text { trabalho. } \\
\text { - Reflexão sobre o manejo transparente dos } \\
\text { recursos econômicos de sua comunidade. } \\
\text { - Realização de informes sobre os ingressos } \\
\text { e egressos e sobre situação econômica de } \\
\text { sua comunidade educativa. }\end{array}$} & $\begin{array}{l}\text { Reflexão crítica sobre o manejo } \\
\text { transparente e responsável de } \\
\text { recursos econômico-financeiros na } \\
\text { comunidade. }\end{array}$ & \multirow{4}{*}{$\begin{array}{l}\text { Informe econômico } \\
\text { transparente e } \\
\text { responsável de } \\
\text { ingresso e egressos } \\
\text { da atividade } \\
\text { socioeconômica para a } \\
\text { tomada de decisões. }\end{array}$} \\
\hline Saber & & & & $\begin{array}{l}\text { - Conceptualização e classificação } \\
\text { dos documentos e registros } \\
\text { contábeis. }\end{array}$ & \\
\hline Fazer & & & & $\begin{array}{l}\text { Elaboração de registros e } \\
\text { documentos contábeis utilizando } \\
\text { adequadamente noções básicas de } \\
\text { contabilidade. }\end{array}$ & \\
\hline Decidir & & & & $\begin{array}{l}\text { - Participação responsável e } \\
\text { comprometida com atividades } \\
\text { socioeconômicas. }\end{array}$ & \\
\hline
\end{tabular}

Fonte: Bolívia (2012a).

(Footnotes)

Nome dado à América por povos originários. 